\title{
MARICULTURE DEVELOPMENT IN INDONESIA: Prospects and Constraints
}

\author{
Michael A. Rimmer\# \\ Faculty of Veterinary Science, University of Sydney, Australia \\ (Received 2 November 2010; Accepted 3 December 2010)
}

\begin{abstract}
Mariculture is an important component of Indonesian fisheries and aquaculture production, directly contributing an estimated US\$320 million in 2008. Because most mariculture production is focussed on producing for export markets, mariculture production is an important source of foreign earnings for the Indonesian economy. This paper reviews the current status and prospects for continuing development of mariculture in Indonesia. Currently the major mariculture commodity in Indonesia is seaweed for carrageenan production. Seaweed production accounts for $98 \%$ of total Indonesian mariculture production and $84 \%$ of value. The other major commodity groups are marine finfish and pearl oysters. Commodities being developed for mariculture in Indonesia include abalone and spiny lobsters. Prospects for continued development of mariculture in Indonesia appear positive. Indonesia has several advantages for mariculture development, including many potential mariculture sites, a stable tropical climate, and does not suffer from cyclonic storms. The Government of Indonesia is planning to increase aquaculture production substantially over the next four years, including mariculture production. Globally, demand for seafood products is expanding due to increasing population and increased per capita consumption of fish products. Constraints to the continued development of mariculture in Indonesia include: limited seed supply, particularly of species which cannot be economically produced in hatcheries, such as spiny lobsters; need to develop more efficient production systems for some marine finfish; the need to improve environmental sustainability by improving feeds and reducing environmental impacts; and market issues relating to environmental sustainability.
\end{abstract}

KEYWORDS: mariculture development, culture system, sustainability

\section{MARICULTURE IN INDONESIA}

This paper reviews the prospects and constraints for the continued development and expansion of mariculture in Indonesia. The term 'mariculture' is used here in the currently widely-accepted sense as the aquaculture of aquatic plants and animals that is undertaken in the sea. It thus excludes coastal aquacul- ture, particularly pond culture. This definition also excludes stock enhancement or marine 'ranching'.

Mariculture is an important contributor to Indonesian fisheries production (Table 1). Based on FAO data (FAO, 2010), the value of maricultured products in Indonesia was over US\$ 320 million in 2008 (Table 2). Because most

\# Corresponding author. ACIAR Field Support Office, Makassar, South Sulawesi, Indonesia E-mail address: aceh_arp@iprimus.com.au 
Indonesian maricultured products are exported, mariculture is also an important contributor to foreign earnings. In Indonesia, the dominant maricultured commodity group is seaweed (mostly Kappaphycus species) which accounts for $98 \%$ of production and $84 \%$ of value of Indonesian mariculture production. The other major commodity groups are marine finfish (including groupers and barramundi) and pearl oysters; while marine (spiny) lobsters and sea cucumbers are relatively small contributors to total production (Table 1, Table 2).

\section{Seaweeds}

Seaweeds are grown for:

- Direct consumption, either as food or for medicinal purposes;

- Production of the commercially valuable polysaccharides alginate and carrageenan;

- Use as fertilisers;

- Feed for other aquaculture commodities, such as abalone and sea urchins.

Although China is the world's largest producer of seaweed, China does not produce the red and brown seaweeds needed for higher end food hydrocolloid production - Indonesia and the Philippines are the main producers of farmed Kappaphycus and Eucheuma species upon which the carrageenan industry depends (Feng et al., 2004; Bixler \& Porse, 2010). A recent review of seaweed markets concluded that while seaweed hydrocolloid markets continue to grow, instead of the 3\%-5\% per annum growth achieved in the 1980s and 1990 s, recent market growth has dropped to 1\%-3\% per year (Bixler \& Porse, 2010).

In addition to the traditional products derived from seaweed, such as agar and carrageenan, there is research into alternative products or value streams. Recent trials at Balai Budidaya Air Payau Takalar, South Sulawesi, were undertaken to evaluate the potential to culture red seaweeds for paper production (S. Raharjo, pers. comm.). The liquid component of seaweeds, which was previously regarded as a waste product, can be used as fertiliser. In Tamil Nadu, India, the liquid component of Kappaphycus is extracted and sold as a horticultural fertiliser. This process can add considerable value to the whole production system, because the liquid component is around $31 / 2$ times as valuable as the dry component ( $\mathrm{M}$. Sakthivel, pers. comm.).

\section{Sea Cucumbers}

FAO data for 2008 report that Indonesia produced 279 tonnes of sea cucumbers from aquaculture (Table 1), valued at about USD 1.1 million (Table 2). However, as Tuwo (2004) notes, much of this production may be classified as fisheries production rather than aquaculture, because many fishers retain their catch, generally sandfish or trepang pasir (Holothuria scabra), in a cage or pond until the number of specimens is large enough to sell or process.

Tuwo (2004) notes the main problems with sea cucumber aquaculture in Indonesia are the long grow-out period and the limited availability of seed. Seed production of $H$. scabra is now well established and the Australian Centre for International Agricultural Research (ACIAR) recently published a hatchery manual (Agudo, 2006). H. scabra seed have been produced by at least two government hatcheries in Indonesia: Research Institute for Mariculture (Balai Besar Riset Perikanan Budidaya Laut Gondol, Bali), and Development Institute for Mariculture (Balai Besar Pengembangan Budidaya Laut Lampung) (Handoko et al., 2005). However, anecdotal reports indicate that farmer interest in their culture was low, due to low growth rates.

There have been several small-scale trials with sea cucumber culture in South Sulawesi: Conand \& Tuwo (1996) undertook growth trials in a small enclosure at Pulau Kambuno, near Sinjai, South Sulawesi, and Konsorsium Mitra Bahari undertook a trial using on-shore tanks at Pulau Badi, South Sulawesi (S. Blankenhorn, pers. comm.).

Despite this limited success to date, there is good potential for culture of $H$. scabra in tambak as a substitute for shrimp culture. Trials with sea cucumber in ponds in Vietnam has demonstrated that $H$. scabra can be successfully and profitably farmed in coastal ponds (Mills et al., 2008), and demand for sea cucumber products, particularly in China, remains high (Chen, 2004).

\section{Molluscs}

Mollusc aquaculture in Indonesia is unusual in that it is focussed on production of pearls rather than on edible bivalves (Table 1). In most Asian countries, edible bivalves dominate mollusc production. Poernomo (2006) provides 

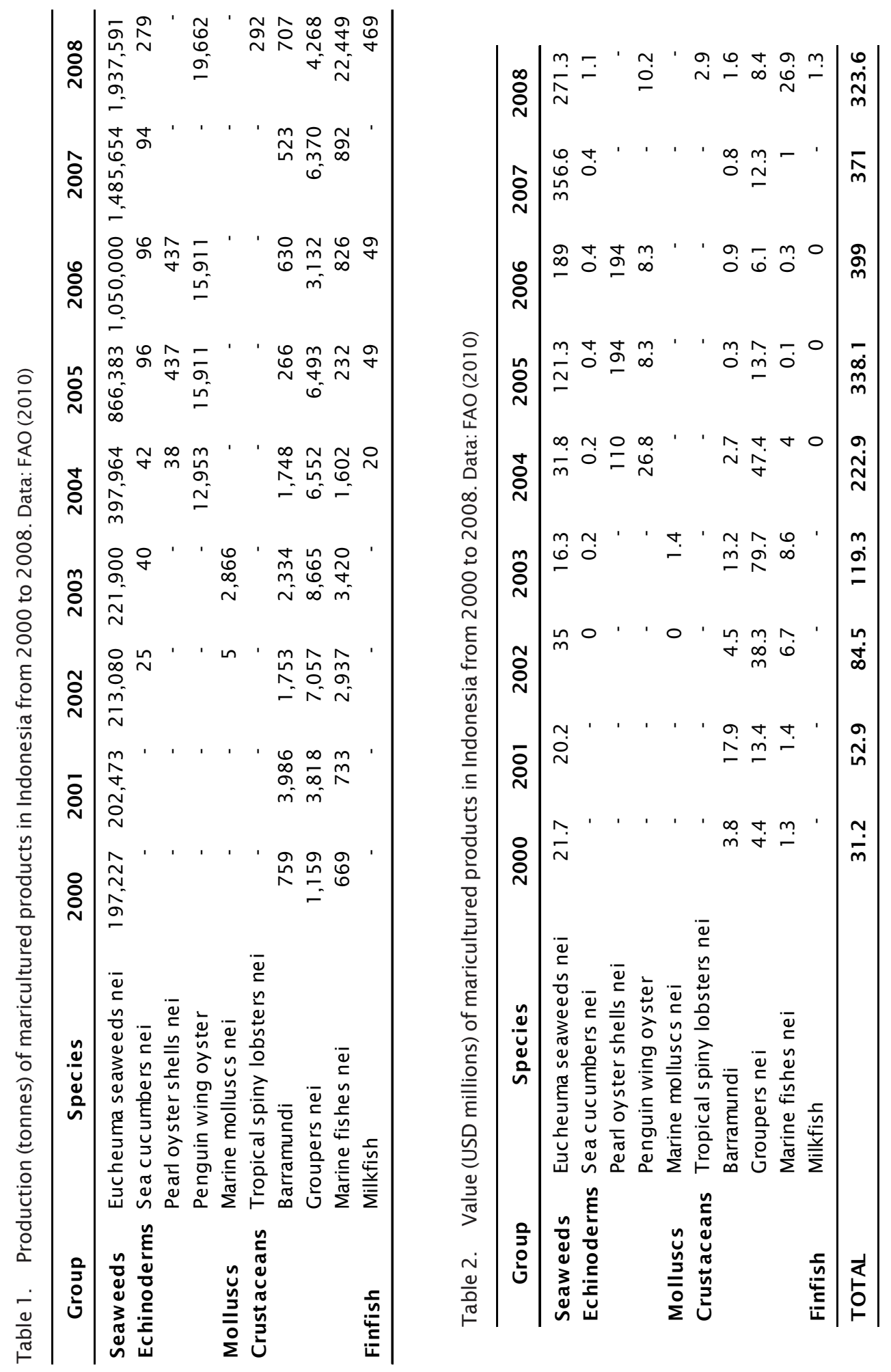
a brief history of pearl farming in Indonesia, including its various 'ups and downs'; Ministry of Marine and Fisheries (Kementerian Kelautan dan Perikanan, KKP) reports that there are currently 71 registered pearl aquaculture development companies in Indonesia, in Bali, Lampung, Lombok, Nusa Tenggara Barat, Nusa Tenggara Timur, Maluku, Papua and Halmahera.

Pearl culture is technically intensive, particularly the process of inserting a nucleus to promote formation of a pearl, and is thus better suited to large-scale commercial ventures. The period between nucleus insertion and harvest generally ranges between 9 months and 3 years. Pearl oysters are usually grown out using suspended culture systems, usually suspended below rafts or on long-lines. The quality of the pearl is related to the length of the culture period, but many insertions are unsuccessful, resulting in the death of the pearl oyster or ejection of the nucleus (Lucas, 2003). Poernomo (2006) notes that one of the factors leading to the success of Indonesian pearl farming has been the transfer of technologies once considered secret (e.g. seeding) and only available through contracting foreign experts, to local people.

There has been substantial interest in selective breeding of pearl oysters, and a joint Indonesian - Australian research project is currently underway to develop appropriate tools and evaluate the practicality of this approach (Evans et al., 2007). Poernomo (2006) notes that the challenge of the future lies in marrying stable production with developing markets and ensuring a balance between supply and demand.

Another mollusc that is currently being developed for mariculture in Indonesia is abalone, which brings prices up to US $\$ 33 / \mathrm{kg}$ (Fermin et al., 2009). Several KKP centres have successfully produced seed of abalone Haliotis asinina and H. squamata. There is also interest in culturing the 'tokubushi' abalone $H$. diversicolor diversicolor, which is marketed as cocktail abalone in China, Japan, Taiwan and Hong Kong (Fermin et al., 2009). Abalone has potential for grow-out in islands throughout Indonesia, particularly eastern Indonesia (Fermin et al., 2009).

\section{Crustaceans}

Although there is substantial production of marine shrimps in Indonesia, all of this produc- tion is undertaken in coastal ponds and thus does not meet the definition of 'mariculture' given above. The same is true of crab culture. Mariculture of crustaceans in Indonesia is effectively limited to spiny rock lobsters (Family Panuliridae).

Tropical spiny rock lobsters are cultured in many parts of Southeast Asia, with the bulk of production in Vietnam and the Philippines. In Vietnam, sea cage culture of lobsters started in the province of Khanh Hoa in the early 1990s and has expanded significantly around southcentral Vietnam since 2000 (Hung \& Tuan, 2009). Panulirus ornatus (ornate spiny lobster) is the dominant cultured species, but several other species, including $P$. homarus, $P$. stimpsoni and $P$. longipes, are also farmed. In 2006 , there were more than 49,000 cages producing approximately $1,900 \mathrm{t}$ of product, valued at about US\$90 million (Hung \& Tuan, 2009). However, since that time production has declined due to the outbreak and widespread impacts of 'milky disease'. In 2007 Vietnamese production was about 1,400 tonnes (Hung \& Tuan, 2009).

Lobster culture has considerable potential in Indonesia (Jones et al., 2007; Pahlevi, 2009; Priyambodo \& Suastika Jaya, 2010). In 2008 Indonesia produced 292 tonnes of lobsters from aquaculture (Table 1) valued at a US\$2.9 milIion (Table 2). However, much of this production may be of lobster held only for short periods ('fattening') either to build up farm production or between visits by collectors / middlemen. Currently, lobster culture is most developed in Lombok where there are three main lobster culture areas: Telong Elong Bay, Awang Bay and Gerupuk Bay (Priyambodo \& Sarifin, 2009). ACIAR is supporting research into lobster puerulus collection in NTB, NTT, South Sulawesi and Aceh (Pulau Simeulue) to identify the composition, seasonal patterns and potential capacity of the lobster puerulus resources in these areas. Where there are adequate seed resources identified, grow-out trials will also be undertaken.

There are several species of spiny lobsters and slipper lobsters (kipas) caught and/or cultured in Indonesia (Table 3). The composition of lobster catches seems to vary between different locations. In Lombok, two lobster species are prevalent in puerulus catches: $P$. ornatus and $P$. homarus. Small numbers of $P$. versicolor and $P$. longipes are also caught (Priyambodo \& 
Table 3. Spiny lobster and slipper lobster species commonly cultured in Indonesia (from Jones et al., 2007)

\begin{tabular}{lll}
\hline Indonesian name & \multicolumn{1}{c}{$\begin{array}{c}\text { Common name } \\
\text { Spiny Lobsters }\end{array}$} & \multicolumn{1}{c}{ Scient ific name } \\
\hline Mutiara & Pearl lobster & $\begin{array}{l}\text { Panulirus ornatus } \\
\text { Pasir }\end{array}$ \\
$\begin{array}{l}\text { Sand lobster } \\
\text { Batik }\end{array}$ & Red lobster & $\begin{array}{l}\text { P. longipes femoristriga } \\
\text { Pakistani }\end{array}$ \\
$\begin{array}{l}\text { Bambu } \\
\text { Batu }\end{array}$ & Bamboo & $\begin{array}{l}\text { P. polyphagus } \\
\text { Kipas }\end{array}$ \\
Kipas merah & Black lobster & P. penicillatus \\
Kipas hitam & Slipper lobsters \\
Kipas tanduk & Red slipper lobster & Scyllarides squammosus \\
Kipas & Black slipper lobster & Parribacus antarcticus \\
& & $?$ \\
\hline
\end{tabular}

Sarifin, 2009). In contrast, sampling in Aceh indicated that $P$. homarus predominates (35\%), followed by $P$. penicillatus (28\%), P. versicolor (21\%), P. longipes (12\%), P. ornatus (2\%), and P. polyphagus (1\%) (Tewfik et al., 2009).

The two main species of lobster farmed in Indonesia are both highly marketable: $P$. homarus at a harvest size of 200 to $300 \mathrm{~g}$ fetches around of IDR 150,000 (H-US\$17) per $\mathrm{kg}$ to the farmer, while $P$. ornatus (300-500 g) sells for IDR 130,000 (H-US\$14) per kg Jones et al., 2007). The price paid for P. ornatus would be higher if the lobsters were grown out to around $1 \mathrm{~kg}$, which is the preferred market size (Priyambodo \& Suastika Jaya, 2009).

Tropical spiny rock lobsters are cultured in cages. In Indonesia, lobster culture cages range in capacity from $3.5 \mathrm{~m}^{3}$ to $64 \mathrm{~m}^{3}$ and are made from synthetic mesh (fish net) of mesh size up to $15 \mathrm{~mm}$, suspended from a floating frame supported on plastic or steel drum floats (Jones et al., 2007; Priyambodo \& Suastika Jaya, 2009). In Vietnam, submerged cages may be used for nursing juvenile lobsters and are located in shallow water. A feeding pipe allows feed to be dropped into the cage, and limits the depth at which this system can be used (Tuan \& Mao, 2004).

To date, hatchery techniques for spiny rock lobster remain experimental and aquaculture is dependent on capture of wild seedstock. Pueruli (the unpigmented settlement stage) or juvenile lobsters are captured after settling, often on fish traps (bagan) (Priyambodo \& Sarifin, 2009). Some farmers collect pueruli using shelter traps, with bundles of rice bags, canvas or netting as the settlement substrate (Priyambodo \& Sarifin, 2009). In Vietnam, coconut logs drilled with holes are also used as settlement collectors. As the industry develops it is likely that a specialised seed capture sector will develop to supply grow-out farms (Priyambodo \& Sarifin, 2009). Catches of pueruli and juvenile lobsters are strongly seasonal, with peak catches in Lombok in November and December (Priyambodo \& Sarifin, 2009).

Hart (2009) surveyed markets for spiny lobster and concluded that China's booming economy and expanding middle class continues to fuel demand for lobster, particularly $P$. ornatus. $P$. ornatus is the most important lobster species used for celebratory events in Southern China. Although live aquacultured $P$. ornatus from Vietnamese are discounted slightly over wild-caught product of the same size, the product overall commands a significantly higher average selling level each year, and continues to find market space for as much as can be produced. Of the major tropical species, $P$. penicillatus is considered as the next preferred species by Asian markets, with $P$. homarus and $P$. longipes achieving similar prices (Hart, 2009).

Slipper lobsters are well known throughout the world and are well-favoured in either frozen or live condition, with higher prices paid 
for live product. In general, the slipper lobsters bring lower prices than spiny lobsters. However, there appears to be ongoing demand and popularity for Scyllarides spp. in the Chinese market which suggests that this might be a profitable option for aquaculture, while the market capacity for both frozen and live Thenus spp. also shows considerable potential (Hart, 2009).

\section{Other Invertebrates}

Sponge aquaculture is generating considerable interest amongst researchers, but commercial production of farmed sponges in the Asia-Pacific region is still experimental. Potential markets for sponges are as bath sponges or in the production of bioactive compounds (de Voogd, 2007a; b; Duckworth et al., 2009). The technology used to produce sponges is similar to that used for seaweed culture: sponges can be propagated vegetatively, and little infrastructure is necessary to establish farms. The harvested product (for bath sponges) can be dried and stored and does not require infrastructure such as refrigeration (Duckworth et al., 2009). Consequently if commercial viability can be demonstrated, sponge aquaculture has considerable potential in Indonesia, particularly in Eastern Indonesia. De Voogd (2007a; b) trialled six species of sponges in South Sulawesi and concluded that only one, Callyspongia (Euplacella) biru, which produces the bioactive compound amphitoxin, exhibited high enough growth rates to have aquaculture potential.

To date, the market acceptance and economic viability of commercial sponge farming has not been established. Further assessment of basic biological parameters, such as growth and survival, as well as development of marketing channels, is necessary before largescale sponge aquaculture can be developed.

There has been some small-scale development of coral farming in the Pacific Islands and, through Konsorsium Mitra Bahari, in South Sulawesi. Both soft and hard corals have been cultured, primarily for the marine aquarium trade, although some hard corals are sold as curios or used for restoration of degraded areas on coral reefs. Corals are propagated vegetatively. Small pieces of live coral are glued to bases, and these are placed on underwater 'tables' fitted with galvanised wire mesh. Growth is reportedly rapid, with aquarium corals reaching harvestable size in 3-12 months. Because of the low level of capital investment needed, and the relatively simple propagation methods used, coral culture is suitable for remote coastal communities where infrastructure may be lacking.

\section{Marine Finfish}

Production technology for marine finfish is well established in Indonesia. While total production, by global standards, is relatively low, a wide range of species are produced, including barramundi / Asian sea bass, groupers and milkfish. In addition, other species, such as cobia, are beginning to emerge as options for Indonesian mariculture production.

Groupers (Family Serranidae, Subfamily Epinephelinae) are a popular commodity for culture in Indonesia. Demand for aquacultured grouper is expanding rapidly in Asia, driven by high prices in the live fish markets of Hong Kong and China, and the decreasing availability of wild-caught product due to overfishing (Sadovy et al., 2003). Grouper production in Indonesia has expanded due to increased availability of fingerlings. Many backyard hatcheries in Bali are now producing grouper fingerlings, particularly the popular tiger grouper (Epinephelus fuscoguttatus). Data on grouper production indicate that the total production for Indonesia fluctuates greatly between years. According to FAO data (Table 1), production peaked in 2003 with about 8,600 tonnes; however, 2008 production was just over 4,200 tonnes.

In Indonesia, most barramundi / Asian sea bass (Lates calcarifer) is produced in sea cages. In other countries, most barramundi production is from brackishwater culture, or, in Australia, from freshwater ponds (Rimmer, 2003). Global production of barramundi has been relatively constant over the past 10 years at around 20,000 - 30,000 tonnes per annum, and Indonesia contributes relatively little $(<1,000$ tonnes) to this total (Table 1$)$.

Milkfish (Chanos chanos) is a popular commodity in Asia and the Pacific. Globally, Indonesia and the Philippines are the largest producers of milkfish, accounting for about $>90 \%$ of production. Milkfish fry (nener) are captured from the wild, or produced in hatcheries. Sudradjat \& Sugama (2010b) estimate that less than $50 \%$ of Indonesia's milkfish fry are sup- 
plied from wild capture. Indonesia is a major producer of milkfish seed, with much of this coming from 'backyard' or small-scale hatcheries (Siar et al., 2002; Sudradjat \& Sugama, $2010 b)$. Most grow-out of milkfish is in brackish water ponds (Sudradjat \& Sugama, 2010a), but recently there has been some production from sea cages. However, in 2008 Indonesian milkfish production from mariculture was less than 500 tonnes (Table 1), compared with 277,000 tonnes of production from brackish water.

Cobia (Rachycentron canadum) is an emerging species of considerable interest to farmers in the Asia-Pacific region. Production of this fast-growing (to $6 \mathrm{~kg}$ in the first year) species is set to expand rapidly, not only in Asia, but also in the Americas. Currently, Indonesia produces only small quantities of cobia from farms in Kepulauan Seribu (Wahjudi \& Michel, 2007) and Lampung.

\section{PROSPECTS AND CONSTRAINTS FOR MARICULTURE DEVELOPMENT IN INDONESIA}

\section{Prospects}

Although Indonesia has many advantages for mariculture development, there are also some constraints to developing this sector further. These are outlined in Table 4.

\section{Government policy and support}

Mariculture development is strongly supported by government policy. The Government of Indonesia plans to substantially increase production of fisheries and aquaculture by 2014 (KKP, 2010). Mariculture production will contribute to this target, with the focus on seaweed, grouper and barramundi production (Table 5).

Mariculture development is also supported by a network of research centres and technical implementation units (TIUs) managed by KKP. For mariculture, the Balai Besar Riset Perikanan Budidaya Laut Gondol (Research Institute for Mariculture Gondol) in Bali and the Balai Riset Perikanan Budidaya Air Payau Maros (Research Institute for Coastal Aquaculture Maros) in South Sulawesi are the main research centres involved in mariculture research and development. Of the Indonesian TIU network, there are four TIUs dedicated to mariculture, located in Lampung, Batam, Lombok and Ambon. In addition, the brackishwater aquaculture TIUs, located in Aceh (Ujung Batee), Central Java (Jepara), East Java (Situbondo), and South Sulawesi (Takalar) also support some mariculture activities. A major role of the TIUs is to stimulate aquaculture production through seedstock production, and the provision of training and technical support services to the aquaculture industry.

Table 4. Summary of advantages and disadvantages of Indonesian mariculture

\begin{tabular}{|c|c|c|}
\hline Factor & Advant age & Disadvant age \\
\hline Geography & $\begin{array}{l}\text { An estimated } 17,000 \text { islands, provide } \\
\text { many sites for maric ulture operations }\end{array}$ & $\begin{array}{l}\text { Lack of infrastruc ture, } \\
\text { partic ularly on small islands }\end{array}$ \\
\hline Climate & $\begin{array}{l}\text { Equatorial position, which brings high } \\
\text { temperatures throughout the year with } \\
\text { relatively little seasonal variation }\end{array}$ & \\
\hline $\begin{array}{l}\text { Natural } \\
\text { disasters }\end{array}$ & $\begin{array}{l}\text { Unlike neighbouring countries, } \\
\text { Indonesia is not subject to cyclonic } \\
\text { storms }\end{array}$ & $\begin{array}{l}\text { Subject to volcanic and } \\
\text { tectonic activity }\end{array}$ \\
\hline Labour & $\begin{array}{l}\text { Availability of workforce; low labour } \\
\text { costs }\end{array}$ & $\begin{array}{l}\text { Lack of semi-skilled and skilled } \\
\text { labour }\end{array}$ \\
\hline \multirow[t]{2}{*}{ Biodiversity } & $\begin{array}{l}\text { High biodiversity provides many } \\
\text { options for mariculture dev elopment }\end{array}$ & $\begin{array}{l}R \& D \text { effort is divided between } \\
\text { many species }\end{array}$ \\
\hline & & $\begin{array}{l}\text { Production of many different } \\
\text { species precludes optimising } \\
\text { production technology for one } \\
\text { or a few species }\end{array}$ \\
\hline
\end{tabular}


Table 5. Planned production of maricultured commodities in Indonesia for the period 2009 to 2014 (KKP, 2010)

\begin{tabular}{crrrrrrr}
\hline $\begin{array}{c}\text { Commodity } \\
\text { (tonnes) }\end{array}$ & 2009 & 2010 & 2011 & 2012 & 2013 & 2014 & $\begin{array}{r}\text { Increase } \\
\text { (\% p.a.) }\end{array}$ \\
\hline Seaweed & $2,574,000$ & $2,672,800$ & $3,504,200$ & $5,100,000$ & $7,500,000$ & $10,000,000$ & $32 \%$ \\
Grouper & 5,300 & 7,000 & 9,000 & 11,000 & 15,000 & 20,000 & $31 \%$ \\
Barramundi & 4,600 & 5,000 & 5,500 & 6,500 & 7,500 & 8,500 & $13 \%$ \\
\hline
\end{tabular}

At the Provincial government level there is a network of 23 Balai Benih Ikan Pantai (Coastal Seed Production Centres), the role of which is to stimulate local aquaculture production by providing seedstock of species such as grouper or seaweed. Reportedly, the success of the BBIP scheme has been mixed but many centres have had only limited production due to lack of training and resourcing.

\section{Market demand}

Unlike some other forms of aquaculture (particularly freshwater aquaculture) which may provide direct protein sources to the farmers' families, mariculture is primarily focussed on producing commodities for sale, either to domestic or export markets. Consequently, mariculture development is driven to a large extent by market demand, and increasingly by international markets for seafood products.

Globally, the demand for seafood products is increasingly being met by aquaculture. Aquaculture now provides almost $50 \%$ of global seafood production. Increase in per capita consumption of seafood, and increasing population are the two factors driving an increasing demand for fish and fishery products on a global basis. FAO estimates that in 2006, 110.5 million tonnes of 'fish' (i.e. aquatic animals) were utilised for human consumption. This provides an estimated average annual global per capita consumption of $16.7 \mathrm{~kg}$ of fish products. The trend since the 1960s has been a steady increase in per capita fish consumption and FAO expects that this trend will continue for the foreseeable future.

In addition, demand for fish products is increasing because of an increasing world population. In 2030 , the world population is expected to reach 8.2 billion. If per capita consumption of $16.7 \mathrm{~kg}$ is to be maintained in 2030 , global demand will be 137.5 million tonnes of fish, representing an increase of 27.1 million tonnes from 2006 production. This increased production will have to be provided by aquaculture because production from capture fisheries has been relatively stable since the late 1980 s and capture fisheries worldwide are generally regarded as fully or over-exploited.

However, as noted below, this overall increase in demand for seafood products is tempered by the increasing demand, particularly in developed country markets, for systems to improve food safety and environmental sustainability.

\section{Constraints to Mariculture Development}

As noted earlier in this paper, Indonesia has many advantages for the continued development of mariculture, as well as a number of disadvantages. Because mariculture production is dominated by commodities produced for export, mariculture development also needs to consider a broad range of external influences. Recently, the issue of sustainability of aquaculture production has become a significant issue in terms of accessing markets for seafood products. The following section lists some of the major constraints to mariculture development in Indonesia, within a context of environmental, economic and social sustainability.

\section{Seed supply}

Seed supply for mariculture comes from two sources: wild populations, where larvae or juveniles are harvested to provide seedstock for grow-out (capture-based aquaculture) and hatchery production of seedstock. Capturebased aquaculture is widely practised in the Asia-Pacific region. However, in general the availability of seed from wild sources is in decline through over-fishing and habitat destruction (Sadovy, 2000; Ottolenghi et al., 2004). Consequently, there is a need to develop sus- 
tainable technologies for seed production, particularly hatchery production.

Hatcheries are producing greater numbers and a wider range of species, but the industry is still reliant on capture of fingerlings for growout, particularly for species that are difficult or costly to raise in hatcheries such as some groupers or Napoleon wrasse Cheilinus undulatus (Sadovy, 2000; Estudillo \& Duray, 2003) or for which there is no established hatchery technology, such as tunas (Ottolenghi et al., 2004) or spiny rock lobsters (Williams, 2004).

The genetic impacts of hatchery production are poorly understood. There are indications that inbreeding in some species has led to a decline in seedstock quality. For example, Frost et al. (2006) found that as many as 55\% of barramundi progeny from one hatchery were the offspring of a single male. Genetic management protocols are required for hatcheries to prevent inbreeding effects in captive populations. There is also a need to develop selective breeding programs for a range of maricultured commodities. Some of the desirable selected traits include: disease resistance, high growth rate, increased thermal tolerance, product colour, and biochemical composition (e.g. carrageenan content in seaweeds). Escapes of cultured animals may have impacts on the environment or on local conspecific populations. Consequently, there is also a need to establish the biodiversity impacts of introductions of new species, and of selectively-bred organisms contributing to wild populations (Nguyen et al., 2009).

\section{Production systems}

With the exception of pearl culture, mariculture in Indonesia is still largely in the hands of small- or medium-scale farms. An emerging trend, particularly for marine finfish culture, is the development of large-scale farms incorporating a range of technologies to improve the cost-efficiency of production. Marine finfish aquaculture in many parts of Asia is adopting the technologies used in Europe originally developed for large-scale salmon production, but the development of larger farms is still limited in Indonesia. These large-scale systems are likely to be more cost-effective for some species (such as cobia) than for others (groupers).

Improving the performance of mariculture production systems through farmer training is made difficult by the large number of small- scale farms which typically contribute to total national production, and the limitations of fisheries and aquaculture extension systems in Indonesia. Current extension systems, variously applied by autonomous provincial and district governments, are often poorly resourced and undervalued, leading to poor service provision and dissatisfaction amongst both extensionists and farmers (Herianto et al., 2010).

\section{Feeds}

So-called 'trash' fish (small, low-value or bycatch fish species) are a major source of feed inputs in aquaculture in the Asia-Pacific region. The term 'trash' fish is inaccurate in that these fish species would not necessarily otherwise be wasted, and alternative uses include reduction to fish sauce for human consumption, protein sources for other agricultural commodities (such as pigs and poultry) or even direct human consumption (New, 1996; Tacon \& Barg, 1998; Edwards et al., 2004; FAO, 2005).

The issues associated with 'trash' fish usage are well documented, most recently in the report of the "APFIC Regional Workshop on Low Value and 'Trash Fish' in the Asia-Pacific Region' (FAO, 2005). Although pellet diets are available for a range of marine finfish as well as some crustaceans, there remain important constraints to the widespread use of compounded diets for aquaculture:

- Farmer acceptance of pellet diets is often low because of the perception that these diets are much more expensive than trash fish. Farmers often do not appreciate that the food conversion ratios of pellet diets (for finfish, usually 1.2-1.8:1) is dramatically better than that of 'trash' fish (usually 510:1, but sometimes higher) and so the relative cost of pellet diets is often comparable, or lower than, the cost of trash fish required to produce the same biomass of fish.

- Variable feed quality, and deterioration due to transport and storage at high temperatures, may also impact substantially on growth and survival of the cultured fish.

- Lack of farmer experience in feeding pellets may result in considerable wastage.

- Fish fed on 'trash' fish may not readily convert to a dry pellet diet, resulting in poor acceptance and perceived lack of appetite. 
- Distribution channels for pelleted feed are not widely available in rural areas. As well as limiting accessibility to the feed, this factor increases the cost of the feed.

- Small-scale fishers or farmers operating fish cages may not have access to the financial resources necessary to invest in purchase of pelleted diets or infrastructure such as refrigeration, finding it easier to collect 'trash' fish themselves, or in small amounts as and when financial or 'trash' fish resources are available. For many farmers, 'trash' fish collection is an opportunity cost which in family-operated farms may be easily absorbed, whereas the purchase of pellets is a cash cost.

\section{Fish health}

Because mariculture in Indonesia is at a relatively early stage of development, and in most cases production is not intensive, it has had relatively few disease problems. Viral nervous necrosis (VNN) is a well-known pathogen of various marine finfish species in hatcheries (Walker \& Winton, 2010), and parasites are a significant problem in grouper farming (W. Sudja, pers. comm.). Rückert et al. (2009) found that a major source of introduction of parasites to farmed grouper was the use of 'trash' fish as a feed, and the use of compounded feeds reduced the incidence of parasite infections.

However, the relative infrequency of disease should not allow complacency. As noted earlier, the decline in production of spiny lobsters in Vietnam is due to the outbreak of 'milky disease' (Hung \& Tuan, 2009). Although the exact cause of 'milky disease' has not been established, it is believed to be associated with unrestricted mariculture development, high stocking densities, and the use of 'trash' fish as feed may be causal factors (Hung \& Tuan, 2009). Fish health issues need to be addressed holistically, taking into account a wide range of environmental factors in addition to the health status of the cultured animals.

\section{Environmental impacts}

Although Indonesian mariculture production is dominated by seaweeds, which can be considered as providing environmental benefits (Neori et al., 2004; Troell et al., 2009), there is a significant production of commodities that require feed inputs, such as marine finfish and crustaceans (lobsters), and it is pro- duction of these high trophic level species that is expanding. Environmental impacts associated with marine finfish and lobster cage aquaculture derive mainly from nutrient inputs from uneaten fish feed and fish wastes (Phillips, 1998). For example, studies carried out in Hong Kong indicate that $85 \%$ of phosphorus, $80 \%$ $88 \%$ of carbon and $52 \%-95 \%$ of nitrogen inputs (from 'trash' fish) to marine finfish cages may be lost through uneaten food, faecal and urinary wastes (Wu, 1995). These nutrient inputs, although small in comparison with other coastal discharges, may lead to localised water quality degradation and sediment accumulation. In severe cases, this 'self pollution' can lead to cage farms exceeding the capacity of the local environment to provide inputs (such as dissolved oxygen) and assimilate wastes, contributing to fish disease outbreaks and consequent mass mortality events.

Where intensity of production is relatively low, the impacts of sea cage aquaculture on coastal waters may be relatively insignificant compared with terrestrial inputs. In one of the few studies of nutrient impacts of marine cage aquaculture in tropical systems, Alongi et al. (2003) found that although fish cages theoretically contributed $26 \%-32 \%$ of nitrogen and $83 \%-99 \%$ of phosphorus to the coastal water studied, there was no evidence of large-scale eutrophication due to the cages, and the effects of the cages was largely swamped by large inputs of organic matter from mangrove forests, fishing villages, fish cages, pig farms and other industries within the catchment. Similarly, a study of sea cage farms in Sumatra and South Sulawesi found that although there was some evidence of benthic enrichment at both farms, there was no clear evidence of impact with distance from the cages at either farm (Alongi et al., 2009). This study also found that phytoplankton gross primary production accounted for $60 \%-77 \%$ of the total organic input to the receiving environment, suggesting that the relative importance of fish cage wastes must be assessed against natural inputs of organic matter (Alongi et al., 2009).

Mariculture inputs may contribute to local fisheries production: Sudirman et al. (2009) found that the biomass of fish surrounding sea cages exceeded the biomass of fish inside the cages, and that wild fish outside the cages consumed a total amount of organic material equivalent to that of the uneaten food leaving the cages, and directly consumed $27 \%$ of the 
lost pellets, significantly reducing organic waste from the cages.

There is increasing appreciation of the environmental impacts of mariculture in Southeast Asia, partly because of the worldwide focus on the environmental impacts of Atlantic salmon farming. However, in most countries there is a lack of legislative frameworks and enforcement. Problems can be addressed by more emphasis on local planning initiatives and co-management frameworks, and zoning of coastal areas for marine fish farming. Hong Kong provides one example where the government has designated marine fish farming zones, however critics argue that zoning has allowed too much crowding and localised water pollution (Lai, 2002; Sadovy \& Lau, 2002). Therefore, zoning of marine fish farming areas has to be accompanied by control measures that limit farm numbers (or fish output, or feed inputs) to ensure effluent loads remain within the capacity of the environment to assimilate wastes (Phillips, 1998). ACIAR has supported improved mariculture planning and zoning in Indonesia through the development of a Cage Aquaculture Decision Support Tool (CADS_TOOL) which was jointly developed by the Australian Institute of Marine Science and Hasanuddin University, South Sulawesi (Halide et al., 2009).

An area of mariculture that is generating some interest is the concept of Integrated Multi-Trophic Aquaculture (IMTA) (Lüning \& Pang, 2003; Neori et al., 2004; Troell et al., 2009). In IMTA systems, nitrogenous wastes produced by fed organisms (e.g. finfish) are removed by cultured macroalgae, reducing the environmental impacts of the overall aquaculture system (Neori et al., 2004; Troell et al., 2009). To date, most research on IMTA systems has been undertaken in temperate environments. The limited amount of research undertaken on tropical systems suggests that bacterial utilisation of dissolved nutrients is much higher, and much more rapid, than is seen in temperate systems and that dissolved nutrients may be largely utilised by bacterial or phytoplankton populations close to the effluent source, and thus availability may be limited for macroalgae production. Overall, the application of IMTA in tropical mariculture systems needs substantially more research to evaluate its potential to improve the environmental sustainability of mariculture.

\section{Markets}

As noted above, many mariculture commodities target international markets. Today, food safety and production sustainability issues are driving developments in these markets, and regulators and industry are developing increasingly stringent requirements in terms of food safety and, increasingly, environmental sustainability issues. While the earlier focus of seafood advisory and certification schemes has been on capture fisheries, more recently they have begun to include aquaculture products (Jacquet \& Pauly, 2007; Belton et al., 2009).

Many such schemes are contentious with aquaculture producers. Some of the issues identified in these schemes include: lack of transparency regarding performance claims and assessment criteria, simplistic and biased assessment criteria, inconsistent application of technical criteria between species and production systems, and discriminatory access to the assessment process. On current indications, such schemes are likely to act as nontariff trade barriers, and particularly restrict market access by smallholder aquaculture farmers (Belton et al., 2009). With mariculture production in Indonesia so highly dependent on small-scale producers, the proliferation of these schemes and their potential impacts on market access may in future be a significant limiting factor to expansion of mariculture in Indonesia as well as in other Asia-Pacific countries.

\section{CONCLUSION}

Indonesia is a major producer of maricultured seafood products, particularly seaweed. The archipelago has many advantages for mariculture production, including site availability and climate. However, infrastructure in many areas that have potential for mariculture development is poor. While Indonesia has a large labour force available for mariculture production, much of this labour force is unskilled. Government policy and support is strong, with a policy to substantially expand mariculture production by 2015 , and a network of research centres and technical implementation units to support mariculture development.

Because mariculture production focuses largely on commodities for export, production systems as well as post-harvest handling and 
processing must take into account the needs of international markets. Increasingly, international markets are demanding improved food safety, including product traceability. An emerging trend is the requirement to demonstrate environmental sustainability for aquaculture production systems, including mariculture production.

Continued development of mariculture in Indonesia will require responses to the constraints identified in this paper. Although Indonesia has a strong R\&D capability, much of the focus has been, and continues to be, on developing seed production technologies for a wide range of species. With the identified need to respond to international market requirements, more R\&D effort needs to be expended on developing and implementing improved food safety systems. This is an extremely challenging task in a country where much of the mariculture production comes from small-scale producers.

\section{ACKNOWLEDGMENTS}

This paper is derived from presentations given at 'Indonesian Aquaculture 2009', held in conjunction with the World Oceans Congress, Manado, North Sulawesi, 12-14 May 2009, and the 'International Seminar: Indonesian Fisheries Development: Enhancing fish production and competitiveness in international market' held at Hasanuddin University, Makassar, South Sulawesi, 22 November 2010. I thank the organisers of both conferences, including the Ministry of Marine Affairs and Fisheries, Indonesia, and the Faculty of Marine Science and Fisheries, Hasanuddin University. I thank Sugeng Raharjo (BBAP Takalar, South Sulawesi), M. Sakthivel (Aquaculture Foundation of India), and Sven Blankenhorn (Mars Symbioscience) and Wajan Sudja (Asosiasi Budidaya Ikan Laut Indonesia) for information provided on mariculture.

\section{REFERENCES}

Agudo, N. 2006. Sandfish hatchery techniques. Australian Centre for International Agricultural Research, Secretariat for the Pacific Community, WorldFish Centre, Canberra and Noumea, $44 \mathrm{pp}$.

Alongi, D.M., Chong, V.C., Dixon, P., Sasekumar, A., \& Tirendi, F. 2003. The influence of fish cage aquaculture on pelagic carbon flow and water chemistry in tidally dominated mangrove estuaries of peninsular Malaysia. Marine Environmental Research, 55: 313333.

Alongi, D.M., McKinnon, A.D., Brinkman, R., Trott, L.A., Undu, M.C., Muawanah, \& Rachmansyah. 2009. The fate of organic matter derived from small-scale fish cage aquaculture in coastal waters of Sulawesi and Sumatra, Indonesia. Aquaculture, 295: 6075.

Belton, B., Little, D., \& Grady, K. 2009. Is responsible aquaculture sustainable aquaculture? WWF and the eco-certification of tilapia. Society \& Natural Resources: An International Journal, 22: 840 - 855.

Bixler, H. \& Porse, H. 2010. A decade of change in the seaweed hydrocolloids industry. Journal of Applied Phycology, p. 1-15.

Chen, J. 2004. Present status and prospects of sea cucumber industry in China. In: Lovatelli, A., Conand, C., Purcell, S., Uthicke, S., Hamel, J.-F., Mercier, A. (Eds.), Advances in Sea Cucumber Aquaculture and Management. Food and Agriculture Organisation of the United Nations, Rome, p. 25-38.

Conand, C. \& Tuwo, A. 1996. Commercial holothurians in South Sulawesi: fisheries and mariculture. SPC Beche-de-mer Information Bulletin, p. 17-21.

de Voogd, N.J. 2007a. An assessment of sponge mariculture potential in the Spermonde Archipelago, Indonesia. Journal of the Marine Biological Association of the UK, 87: 1,777-1,784.

de Voogd, N.J. 2007b. The mariculture potential of the Indonesian reef-dwelling sponge Callyspongia (Euplacella) biru: growth, survival and bioactive compounds. Aquaculture, 262: 54-64.

Duckworth, A., Wolff, C., \& Evans-Illidge, E. 2009. Farming bath sponges in tropical Australia, World Aquaculture, p. 20-22, 70.

Edwards, P., Tuan, L.A., \& Allan, G.L. 2004. A survey of marine trash fish and fish meal as aquaculture feed ingredients in Vietnam. ACIAR Working Paper No. 57. Australian Centre for International Agricultural Research, Canberra, 56 pp.

Estudillo, C.B. \& Duray, M.N. 2003. Transport of hatchery-reared and wild grouper larvae, Epinephelus sp. Aquaculture, 219: 279-290.

Evans, B.S., Kanuer, J., Taylor, J.J.U., \& Jerry, D.R. 2007. Progress towards a selective breeding program for silver- or gold-lip pearl oys- 
ters Pinctada maxima in Indonesia. Aquaculture, 272: S254-S254.

FAO. 2005. APFIC Regional Workshop on Low Value and 'Trash Fish' in the Asia-Pacific Region. Food and Agriculture Organisation of the United Nations, Regional Office for Asia and the Pacific, Bangkok, $32 \mathrm{pp}$.

FAO. 2010 . FISHSTAT Plus - Universal software for fishery statistical time series. Aquaculture production 1950-2008. FAO Fisheries and Aquaculture Information and Statistics Service. Food and Agriculture Organisation of the United Nations, Rome.

Feng, Y.Y., Hou, L.C., Ping, N.X., Ling, T.D., \& Kyo, C.I. 2004. Development of mariculture and its impacts in Chinese coastal waters. Reviews in Fish Biology and Fisheries, 14: 1-10.

Fermin, A.C., Encena, V.C., Suriawan, A., Hamka, I.J.E., \& Kusumaningtyas, W. 2009. Abalone industry enhancement in eastern Indonesia. SADI-ACIAR Research Report C2007/ 102. Australian Centre for International Agricultural Research, Canberra, 19 pp.

Frost, L.A., Evans, B.S., \& Jerry, D.R. 2006. Loss of genetic diversity due to hatchery culture practices in barramundi (Lates calcarifer). Aquaculture, 26: 1,056-1,064.

Halide, H., Stigebrandt, A., Rehbein, M., \& McKinnon, A.D. 2009. Developing a decision support system for sustainable cage aquaculture. Environmental Modelling \& Software, 24: 694-702.

Handoko, D., Hermawan, A., \& Sudjiharno. 2005. Hatchery of sea cucumber Holothuria scabra. SPC Beche-de-mer Information Bulletin, 22: 61.

Hart, G. 2009. Assessing the South-East Asian tropical lobster supply and major market demands. SADI - ACIAR Research Report FR2009-06. Australian Centre for International Agricultural Research, Canberra, 55 pp.

Herianto, A.S., Wastutinigsih, S.P., Foster, D., Rimmer, M., \& Callinan, R. 2010. Agricultural and fisheries extension in Indonesia - origins, transitions and current challenges. Extension Farming Systems Journal, 6: 2331.

Hung, L.V. \& Tuan, L.A. 2009. Lobster sea cage culture in Vietnam. In: Williams, K.C. (Ed.), Spiny lobster aquaculture in the Asia-Pacific region. Proceedings of an international symposium held at Nha Trang, Vietnam, 9-10 December 2008. Australian Centre for
International Agricultural Research. ACIAR Proceedings 132, Canberra, p. 10-17.

Jacquet, J.L. \& Pauly, D. 2007. The rise of seafood awareness campaigns in an era of collapsing fisheries. Marine Policy, 31 : 308313.

Jones, C., Suastika Jaya, I.B.M., Sukardi, F., \& Surahman, A. 2007. Improving lobster growout and nutrition in Nusa Tenggara Barat - a feasibility study. Australian Centre for International Agricultural Research, Canberra, 23 pp.

KKP. 2010. Peraturan Menteri Kelautan dan Perikanan Nomor Per. 06/MEN/2010 tentang Rencana Strategis Kementerian Kelautan dan Perikanan 2010-2014. Kementerian Kelautan dan Perikanan, Jakarta, $26 \mathrm{hlm}$.

Lai, L.W.C. 2002. An overview of research on aquaculture economics and management in Hong Kong. Aquaculture Economics and Management, 6: 131-152.

Lucas, J. 2003. 21 -Bivalves. In: Lucas, J., Southgate, P.C. (Eds.), Aquaculture - Farming Aquatic Animals and Plants. Blackwell Publishing Ltd, Oxford, UK, p. 443-466.

Lüning, K. \& Pang, S. 2003. Mass cultivation of seaweeds: current aspects and approaches. Journal of Applied Phycology, 15: 115-119.

Mills, D., Duy, N.D.Q., \& Johnston, W. 2008. Review of sandfish pond-culture progress in Vietnam. Final report for ACIAR project FIS/2007/1 17. Australian Centre for International Agricultural Research, Canberra.

Neori, A., Chopin, T., Troell, M., Buschmann, A.H., Kraemer, G.P., Halling, C., Shpigel, M., \& Yarish, C. 2004. Integrated aquaculture: rationale, evolution and state of the art emphasizing seaweed biofiltration in modern mariculture. Aquaculture, 231: 361-391.

New, M.B. 1996. Responsible use of aquaculture feeds, Aquaculture Asia, p. 3-15.

Nguyen, T.T.T., Davy, F.B., Rimmer, M.A., \& De Silva, S.S. 2009. Use and exchange of genetic resources of emerging species for aquaculture and other purposes. Reviews in Aquaculture, 1:260-274.

Ottolenghi, F., Silvestri, C., Giordano, P., Lovatelli, A., \& New, M.B. 2004. Capturebased aquaculture. The fattening of eels, groupers, tunas and yellowtails. Food and Agriculture Organisation of the United $\mathrm{Na}$ tions, Rome, 308 pp. 
Pahlevi, R.S. 2009. Potential for co-management of lobster seacage culture: a case study in Lombok, Indonesia. In: Williams, K.C. (Ed.), Spiny lobster aquaculture in the Asia-Pacific region. Proceedings of an international symposium held at Nha Trang, Vietnam, 9-10 December 2008. Australian Centre for International Agricultural Research. ACIAR Proceedings 132, Canberra, 26 pp.

Phillips, M.J. 1998. Chapter 2 - Tropical Mariculture and Coastal Environmental Integrity. In: De Silva, S.S. (Ed.), Tropical Mariculture. Academic Press, London, p. 17-69.

Poernomo, B.P. 2006. South Sea pearling in Indonesia: past, present and future, Pearl Oyster Information Bulletin. Secretariat of the South Pacific Community, 20 pp.

Priyambodo, B. \& Sarifin, 2009. Lobster aquaculture industry in eastern Indonesia: present status and prospects. In: Williams, K.C. (Ed.), Spiny lobster aquaculture in the Asia-Pacific region. Proceedings of an international symposium held at Nha Trang, Vietnam, 9-10 December 2008. Australian Centre for International Agricultural Research. ACIAR Proceedings 132, Canberra, p. 36-45.

Priyambodo, B. \& Suastika Jaya, I.B.M. 2009. Lobster aquaculture In Eastern Indonesia - Part I. Methods evolve for fledgling industry, Global Aquaculture Advocate, p. 36-39.

Priyambodo, B. \& Suastika Jaya, I.B.M. 2010. Lobster aquaculture In Eastern Indonesia - Part II. Ongoing research examines nutrition, seed sourcing, Global Aquaculture Advocate, p. 32-34.

Rimmer, M.A. 2003. Chapter 18 - Barramundi. In: Lucas, J.S., Southgate, P.C. (Eds.), Aquaculture: Farming Aquatic Animals and Plants. Blackwell Publishing, Oxford, p. 364-381.

Rückert, S., Klimpel, S., Al-Quraishy, S., Mehlhorn, H., \& Palm, H. 2009. Transmission of fish parasites into grouper mariculture (Serranidae: Epinephelus coioides (Hamilton, 1822)) in Lampung Bay, Indonesia. Parasitology Research, 104: 523-532.

Sadovy, Y. 2000. Regional survey of fry/fingerling supply and current practices for grouper mariculture: evaluating current status and long-term prospects for grouper mariculture in Southeast Asia. University of Hong Kong, Hong Kong SAR, China, 120 pp.

Sadovy, Y.J. \& Lau, P.P.F. 2002. Prospects and problems for mariculture in Hong Kong associated with wild-caught seed and feed.
Aquaculture Economics and Management, 6: 177-190.

Sadovy, Y.J., Donaldson, T.J., Graham, T.R., McGilvray, F., Muldoon, G.J., Phillips, M.J., Rimmer, M.A., Smith, A., \& Yeeting, B. 2003. While Stocks Last: The Live Reef Food Fish Trade. Asian Development Bank, Manila, Philippines, $147 \mathrm{pp}$.

Siar, S.V., Johnston, W.L., \& Sim, S.Y. 2002. Study on Economics and Socio-economics of Small-scale Marine Fish Hatcheries and Nurseries, with Special Reference to Grouper Systems in Bali, Indonesia. 36 pp. Report prepared under APEC Project FWG 01/ 2001 - 'Collaborative APEC Grouper Research and Development Network'. AsiaPacific Marine Finfish Aquaculture Network Publication 2/2002. Network of Aquaculture Centres in Asia-Pacific, Bangkok, Thailand, $36 \mathrm{pp}$.

Sudirman, Halide, H., Jompa, J., Zulfikar, Iswahyudin, \& McKinnon, A.D. 2009. Wild fish associated with tropical sea cage aquaculture in South Sulawesi, Indonesia. Aquaculture, 286: 233-239.

Sudradjat, A. \& Sugama, K. 2010 a. Chapter 3 Aquaculture of milkfish (bandeng) in Indonesia: grow-out culture. In: Liao, I.C., Leaño, E.M. (Eds.), Milkfish Aquaculture in Asia. Asian Fisheries Society, World Aquaculture Society, the Fisheries Society of Taiwan and National Taiwan Ocean University, Quezon City, Philippines; Baton Rouge, USA; Keelung, Taiwan, p. 17-30.

Sudradjat, A. \& Sugama, K. 2010b. Chapter 2 Aquaculture of milkfish (bandeng) in Indonesia: fry and fingerling production. In: Liao, I.C., Leaño, E.M. (Eds.), Milkfish Aquaculture in Asia. Asian Fisheries Society, World Aquaculture Society, the Fisheries Society of Taiwan and National Taiwan Ocean University, Quezon City, Philippines; Baton Rouge, USA; Keelung, Taiwan, p. 9-16.

Tacon, A.G.J. \& Barg, U.C. 1998. Chapter 6 - Major Challenges to Feed Development for Marine and Diadromous Finfish and Crustacean Species. In: De Silva, S.S. (Ed.), Tropical Mariculture. Academic Press, London, p. 171-207.

Tewfik, A., Mills, D., \& Adhuri, D. 2009. Spiny lobster resources and opportunity for culture in post-tsunami Aceh, Indonesia. In: Williams, K.C. (Ed.), Spiny lobster aquaculture in the Asia-Pacific region. Proceedings of an international symposium held at Nha 
Trang, Vietnam, 9-10 December 2008. Australian Centre for International Agricultural Research. ACIAR Proceedings 132, Canberra, p. 27-34.

Troell, M., Joyce, A., Chopin, T., Neori, A., Buschmann, A.H., \& Fang, J.G. 2009. Ecological engineering in aquaculture - potential for integrated multi-trophic aquaculture (IMTA) in marine offshore systems. Aquaculture, 297: 1-9.

Tuan, L.A. \& Mao, N.D. 2004. Present status of lobster cage culture in Vietnam. In: Williams, K.C. (Ed.), Spiny lobster ecology and exploitation in the South China Sea region - Proceedings of a workshop held at the Institute of Oceanography, Nha Trang, Vietnam, July 2004. ACIAR Proceedings No. 120. Australian Centre for International Agricultural Research, Canberra, p. 21-25.

Tuwo, A. 2004. Status of sea cucumber fisheries and farming in Indonesia. In: Lovatelli, A., Conand, C., Purcell, S., Uthicke, S., Hamel, J.-F., Mercier, A. (Eds.), Advances in Sea Cucumber Aquaculture and Management. FAO Fisheries Technical Paper,
No.463. Food and Agriculture Organisation of the United Nations, Rome, p. 49-55.

Wahjudi, B. \& Michel, A. 2007. Cobia aquaculture in Indonesia. In: Liao, I.C., Leaño, E.M. (Eds.), Cobia Aquaculture-Research, Development and Commercial Production. Asian Fisheries Society, World Aquaculture Society, the Fisheries Society of Taiwan and National Taiwan Ocean University, Quezon City, Philippines; Baton Rouge, USA; Keelung, Taiwan, p. 105-114.

Walker, P.J. \& Winton, J.R., 2010. Emerging viral diseases of fish and shrimp. Veterinary Research, 41: 51-74.

Williams, K.C. 2004. Spiny lobster ecology and exploitation in the South China Sea region. Proceedings of a workshop held at the Institute of Oceanography, Nha Trang, Vietnam, July 2004. ACIAR Proceedings No.120. Australian Centre for International Agricultural Research, Canberra, 73 pp.

Wu, R. 1995. The environmental impact of marine fish culture: towards a sustainable future. Marine Pollution Bulletin, 31: 159-166. 